\title{
Ian McEwan - Novels about Neurological and Psychiatric Patients
}

\author{
Uroš Rot \\ Department of Neurology, Medical Centre, Ljubljana, Slovenia
}

\section{Key Words}

lan McEwan · Neurology $\cdot$ Psychiatry $\cdot$ Huntington's

disease $\cdot$ Variant Creutzfeldt-Jakob disease $\cdot$ de Clerambault syndrome

\begin{abstract}
Ian McEwan, a respected contemporary British writer, sometimes uses neurological and psychiatric patients as main characters of his stories. In his recent novels one can find beautiful descriptions of patients with Huntington's disease, variant Creutzfeldt-Jakob disease, de Clerambault syndrome and also details about some neurosurgical procedures.
\end{abstract}

Copyright $\odot 2008$ S. Karger AG, Basel

\section{Introduction}

Ian McEwan is a respected British writer. He was born in Aldershot (England) in 1948 and studied literature at the University of Sussex. After graduating from Malcolm Bradbury's creative writing programme he immediately won the Somerset Maugham Award for the collection of short stories First Love, Last Rites in 1975. He was nominated three times for prestigious Booker Prize and secured the honour with the novel Amsterdam in 1998 . He has also written three television plays, a children's book, a libretto and a film script.

McEwan's early works First Love, Last Rites and The Cement Garden (1978) are notorious for their extreme themes: murder, paedophilia, violence. In his subsequent writings he has moved from the more disquieting of the themes, but continues to explore the impact of unusual and extreme situations on ordinary people. He has begun to address broader themes, examining how social and political issues determine personal lives.

In his late works McEwan has been using neurological and psychiatric patients as important characters of his stories.

\section{Saturday}

Saturday [1] is a novel about a single day in the life of neurosurgeon Henry Perowne. The setting is pessimistic, in post 9/11 London, with crowds massing to protest against impending war in Iraq. On his way to a squash game a minor car accident brings Perowne into a confrontation with a local thug, Baxter.

Perowne notices Baxter's gait: 'His gait is distinctive, with a little jazzy twist and dip of his trunk, as though he is punting along a gentle stretch of river', and his restlessness: 'He is a fidgety, small-faced young man.'

Perowne is more and more certain about Baxter's disease:

It isn't simply a tremor, it's a fidgety restlessness implicating practically every muscle... As Baxter stares at the marchers, he makes tiny movements with his head, little nods and shakes. Perowne suddenly understands - Baxter is unable to initiate or make saccades, those flickering changes of eye position from one fixa-

\section{KARGER}

Fax +41613061234

E-Mail karger@karger.ch

www.karger.com
(C) 2008 S. Karger AG, Basel

0014-3022/08/0601-0012\$24.50/0

Accessible online at:

www.karger.com/ene
Uroš Rot, $\mathrm{MD}, \mathrm{PhD}$

Department of Neurology, Medical Centre

Zaloška 2

1525 Ljubljana (Slovenia)

Tel. +386 152243 19, Fax +386 1522 52 57, E-Mail uros.rot@guest.arnes.si 
tion to another. To scan the crowd, he is having to move his head.

Interpreting fidgety as chorea and noticing head thrust eye movements Perowne is certain that Baxter suffers from Huntington's disease.

In the lines that follow McEwan gives a literary description of Huntington's disease:

If a parent has it, you have a fifty-fifty chance of going down too. Chromosome four. The misfortune lies within a single gene, in an excessive repeat of single sequence - CAG. Here's biological determinism in its purest form. More than forty repeats of that one little codon, and you're doomed. Your future is fixed and easily foretold. The longer the repeat, the earlier and more severe the onset.

Recognising Baxter's disease and promising the treatment Perowne takes control and escapes a mugging. But Baxter returns the same evening and starts to terrorise Perowne's family...

McEwan is also impressed with Perowne's hard-working daily routine and follows him to operating theatres. Perowne was indeed very busy. With the help of two registrars he managed to perform altogether nine operating procedures in a single day. First he made a radiofrequency thermocoagulation of the gasserian ganglion, followed by clipping the neck of a middle cerebral artery aneurysm, stereotactic biopsy of a thalamic tumour, craniotomy for meningioma, multilevel laminectomy for spinal canal stenosis, craniotomy for vestibular schwannoma, readjustment of a spinal stimulator, and craniotomy for resection of frontal glioma. His last operating procedure was the most demanding, a removal of a cerebellar pilocytic astrocytoma in a 14-year-old girl. A description of the operating procedure for trigeminal neuralgia is given in the text:

He slipped a gloved forefinger into the back of her mouth to feel the route, then, with barely a glance at the image intensifier, slid a long needle through the outside of her cheek, all the way up to the trigeminal ganglion... Electrical stimulation of the needle's tip caused a tingling in her face, and once she'd drowsily confirmed the position was correct - Perowne had it right first time - she was put down again while the nerve was 'cooked' by radiofrequency thermocoagulation. The delicate trick was to eliminate her pain while leaving her an awareness of light touch - all done in fifteen minutes; three years' misery, of sharp stabbing pain, ended.

\section{Amsterdam}

The Booker award-winning novel Amsterdam [2] is a provoking contemporary morality tale. On a February day, Clive Lively, a successful modern composer, and Ver- non Halliday, an editor, two old friends and former lovers of Molly Lane meet at her funeral. In the days that follow the funeral Clive and Vernon make disastrous moral decisions with consequences neither had foreseen...

The beginning of the story describing Molly's rapidly progressive illness is very interesting for neurologists:

It began with a tingling in her arm as she raised it outside the Dorchester Grill to stop a cab - a sensation that never went away. Within weeks she was fumbling for the names of things. Parliament, chemistry, propeller she could forgive herself, but less so bed, cream, mirror. It was after the temporary disappearance of acanthus and bresaiola that she sought medical advice, expecting reassurance. Instead, she was sent for tests and, in a sense, never returned. How quickly feisty Molly became the sickroom prisoner of her morose, possessive husband, George. Molly, restaurant critic, gorgeous wit, and photographer, the daring gardener, who had been loved by the foreign secretary and could still turn a perfect cartwheel at the age of forty-six. The speed of her descent into madness and pain became a matter of common gossip: the loss of control of bodily function and with it all sense of humour, and then the tailing off into vagueness interspersed with episodes of ineffectual violence and muffled shrieking... to die that way, with no awareness, like an animal. To be reduced, humiliated.

From the description a neurologist can easily determine that Molly, a 46-year-old restaurant critic, suffered from rapidly progressive dementia, which started with sensory symptoms, followed by cognitive; an example of nominal aphasia is given in the text, and psychiatric symptoms. The differential diagnosis of rapidly progressive dementia is wide, but the time (the nineties), the setting (London), and also Molly's profession strongly suggest that she had variant Creutzfeldt-Jakob disease.

\section{Enduring Love}

Enduring Love [3] starts with a spectacular accident: a balloon with a young boy trapped in it is tossed by the wind, and in an attempt to save the child, a man is killed. Joe Rose, a science writer and a witness to the accident, briefly meets young Jed Parry, which changes his life. Parry, a disturbed young man, becomes obsessed with him, and that threatens Rose's scientific career and loving relationship with his wife.

Parry suffers from de Clerambault syndrome. De Clerambault syndrome or pure erotomania is a psychosis where a patient, often a woman, has a belief that a person, usually of a higher social standing, is in love with her. The patient often has little or no contact with the object of the delusion. The patient believes that the object will never find happiness without her, and that the relationship is 
universally acknowledged. The patient also has a conviction that the object was first to fall in love and was first to make advances in the form of secret signals.

Parry assisted at the scene of an accident involving a helium balloon and exchanged a glance with Rose, who appeared to Parry to fall in love with him at that moment. Late that night Parry made the first of many phone calls to Rose to let him know that the love was mutual. Afterwards Parry harassed Rose with numerous phone calls, letters, and doorstep confrontations. Parry perceived love messages from Rose in the changing arrangements of curtains, and also from published articles by Rose that appeared in print long before their first meeting. Rose's relationship with his wife was under strain because of Parry's determined onslaught and they separated. Parry was euphoric when the couple broke up, certain that despite Rose's hostility, he would come to accept his fate and live with him in his house. Soon the euphoria turned to resentment and Parry hired contract killers to shoot Rose...

As an appendix of Enduring Love McEwan included a report on a similar case of de Clerambault syndrome reprinted from the British Review of Psychiatry and written by Dr. Robert Wenn and Antonio Camia.

However, neither the British Review of Psychiatry nor the authors exist, the last names of the doctors are in fact an anagram for Ian McEwan. A psychiatrist who reviewed Enduring Love in the Bulletin was tricked by the hoax and described it as being based on a published case report.

\section{On Chesil Beach}

On Chesil Beach [4] is a novel about lives transformed by a simple gesture not made and a word not spoken. Edward and Florence, a young couple, come to enjoy their wedding night at a Dorset hotel. Very much in love, and predictably nervous, but unable to discuss their fears and needs before the wedding night, a momentary misunderstanding changes their lives forever...

Edward is an earnest young history student at University College of London who unexpectedly wooed and won the heart of Florence, a young musician. His confidence and independence which attract Florence are a consequence of his mother's disease: 'He could not remember the time, around his fifth birthday when she had abruptly changed.' McEwan describes perseverative behaviour indicating frontal lobe damage: 'She could be heard at any hour of the day, and even in the middle of the night, fum- bling her way through the same simple piano pieces, always faltering in the same places'.

At the age of 14 Edward was told that his mother was injured. Ian McEwan poetically describes the accident: 'The heavy metal edge struck Marjorie Mayhew's forehead with sufficient force to fracture her skull, and dislocate in an instant her personality, intelligence and memory'.

\section{Conclusion}

All the neurological and psychiatric patients mentioned play very important roles in the novels written by Ian McEwan.

In Saturday and Enduring Love patients with Huntington's disease and de Clerambault syndrome can be viewed as the main characters of the novels. Their diseases contribute to the creation of the stories. In Saturday McEwan gives an ingenious parallel between the insecurity and unpredictability of life in the western world after the terrorist attacks in the USA and the unpredictable behaviour of a patient with Huntington's disease. In Enduring Love he offers a parable of a struggle to overcome difficulties and obstacles of a modern marriage with a struggle to fight the psychotic behaviour of de Clerambault syndrome.

Sometimes, as in Amsterdam, McEwan is fascinated by a devastating new disease, like variant CreutzfeldtJakob disease, reports of which filled British media in the nineties, and he uses it as a great introduction to the novel.

Other writers also introduced neurological patients to their novels. Some of Dostoevsky's characters have neurological diseases, for example prince Mishkin, the main character from The Idiot, who suffers from epilepsy [5].

Thomas Mann enriched the characters in Doctor Faustus with neurological diseases, such as hemifacial spasm, migraine and essential tremor [6,7]. He also used a patient suffering from neurological illness as a main character in Doctor Faustus. Adrian Leverkühn, a composer, trades his body and soul to the devil to become a musician of genius. In the novel the devil is presented as a magical black-eyed prostitute and Leverkühn's geniality comes from neurosyphilis he contracted from the prostitute [7].

Writing about patients with neurological diseases demands specific knowledge and diligent preparation by the novelist. For sure, McEwan would not be able to describe neurosurgical operations and neurological signs without studying the literature about neurological dis- 
eases, discussing neurosurgical operations with surgeons, and perhaps even visiting an operating theatre...

His vivid descriptions are also something to be reflected on by neurologists. He was accurate and exact about characteristics of particular diseases. His cases were certainly not based only on detailed knowledge of particular diseases, but also on good observations of people. McEwan was also able to describe the neurological diseases in such a way that the reader can easily recognise neurological entities. After all, the ability to observe and precisely document his findings are qualities of a good clinician.

Furthermore, McEwan also introduced an interesting writing technique, a form of a scientific article, which one can enjoy in an appendix of Enduring Love.

To conclude, the novels by Ian McEwan show us how attractive neurological diseases can be for writers with an interest in medicine and how spectacular novels can be written by a creative storyteller armed with such knowledge.
References
1 McEwan I: Saturday. London, Vintage, 2005.

2 McEwan I: Amsterdam. London, Vintage, 1997.

3 McEwan I: Enduring Love. London, Vintage, 1998.

4 McEwan I: On Chesil Beach. London, Cape, 2007.
5 Dostoevsky FM: The Idiot. London, Penguin, 2004.

6 Mann T: Doctor Faustus: The Life of the German Composer Adrian Leverkühn as Told by a Friend. New York, Vintage, 1999.

7 Rot U: Thomas Mann: neurological cases from Doctor Faustus. Pract Neurol 2004;4: 180-183. 